\title{
GEOGRAPHIC VARIATION IN RESPONSE OF PINE ENGRAVER, Ips pini, AND ASSOCIATED SPECIES TO PHEROMONE, LANIERONE
}

\author{
D. R. MILLER, ${ }^{1, *}$ K. E. GIBSON, ${ }^{2}$ K. F. RAFFA, ${ }^{3}$ \\ S. J. SEYBOLD, ${ }^{4,5}$ S. A. TEALE, ${ }^{6}$ and D. L. WOOD ${ }^{7}$ \\ 'Phero Tech Inc. \\ 7572 Progress Way \\ Delta, British Columbia V4G IE9, Canada \\ ${ }^{2}$ U.S.D.A. Forest Service \\ P.O. Box 7669 \\ Missoula, Montana 59807 \\ ${ }^{3}$ Department of Entomology, University of Wisconsin \\ Madison, Wisconsin 53706 \\ ${ }^{4}$ U.S.D.A. Forest Service \\ P.O. Box 245 \\ Berkeley, California 94701 \\ ${ }^{6}$ Department of Environmental and Forest Biology \\ College of Environmental Science and Forestry, State University of New York \\ Syracuse, New York 13210 \\ ${ }^{7}$ Division of Insect Biology, Environmental Science, Policy and Management \\ University of California \\ Berkeley, California 94720
}

(Received March 25, 1996; accepted April 7, 1997)

\begin{abstract}
Lanierone strongly synergized the attraction of male and female Ips pini (Say) to ipsdienol in New York and Wisconsin. Synergy was only weakly significant in Montana and British Columbia and not significant in California. Catches of $I$. pini in ipsdienol-baited traps were increased $0 \%$ (i.e., nonsignificant) to $9942 \%$ by lanierone, with the highest increases in eastern North America. Lanierone had the least effect in California. The effects of lanierone on sex ratios of $I$. pini in trap catches varied significantly between regions. The addition of lanierone to ipsdienol-baited traps resulted in a general increase in male representation at nine of 12 sites. Ips integer (Eichhoff) was attracted to lanierone alone. Ipsdienol reduced the response of $I$. integer
\end{abstract}

* To whom correspondence should be addressed at: D. R. Miller Consulting Services, Suite 1201-13353 108th Avenue, Surrey, British Columbia V3T 5T5, Canada.

${ }^{5}$ Current Address: Department of Biochemistry, University of Nevada, Reno, Nevada 89557-0014. 
to lanierone. Enoclerus lecontei (Wolcott) (Cleridae) preferred traps baited with the combination of ipsdienol and lanierone. $(R)-(-)$-Ipsdienol was attractive to E. sphegeus (F.), Thanasimus undatulus (Say) (Cleridae), and Temnochila chlorodia (Mannerheim) (Trogositidae), while racemic ipsdienol was attractive to E. nigrifrons var. gerhardi Wolc. and Thanasimus dubius (F.). Lanierone had no effect on these species.

Key Words-Ips pini, Ips integer, Coleoptera, Scolytidae, aggregation pheromone, lanierone, ipsdienol, geographic variation, synergism, Enoclerus lecontei, Cleridae, kairomone.

\section{INTRODUCTION}

The pine engraver, Ips pini (Say) (Coleoptera: Scolytidae), uses the enantiomers of ipsdienol (2-methyl-6-methylene-2,7-octadien-4-ol) as aggregation pheromones (Stewart, 1975; Birch et al., 1980; Lanier et al., 1980). In New York, males produce both $(R)-(-)$ - and $(S)-(+)$-ipsdienol, and both sexes prefer blends with roughly equal ratios of $(R)-(-)$ - and $(S)$ - $(+)$-ipsdienol over blends enriched with either enantiomer (Lanier et al., 1980; Teale, 1990; Teale and Lanier, 1991 ). Males in California produce primarily $(R)-(-)$-ipsdienol (Stewart, 1975; Birch et al., 1980; Miller et al., 1989a; Seybold, 1992; Seybold et al., 1995). Californian beetles are attracted to $(R)-(-)$-ipsdienol (Birch et al., 1980; Seybold, 1992). Attraction to $(R)-(-)$-ipsdienol is interrupted by $(S)$-( +$)$-ipsdienol. In southeastern British Columbia, males produce primarily $(R)-(-)$-ipsdienol as in California (Miller et al., 1989a, 1996; Seybold et al., 1995), but both sexes are attracted to a broader range of enantiomeric mixtures [98:2 to 20:80 $(R)-(-):(S)-(+)$, inclusively] (Miller et al., 1996) than Californian beetles (Birch et al., 1980; Seybold, 1992). In contrast to most other western populations, males in southwestern British Columbia produce ipsdienol with a mean enantiomeric composition of 34:66 $(R)-(-):(S)-(+)$ (Miller et al., 1989a, 1996) and a pooled composition of 39:61 $(R)-(-):(S)-(+)$ (Seybold et al., 1995). In this area, both sexes are attracted to intermediate enantiomeric mixtures [70:30 to 20:80 $(R)-(-):(S)-(+)$, inclusively] (Miller, 1990; Miller et al., 1996). Beetles in Wisconsin prefer an enantiomeric mixture of $25: 75(R)-(-):(S)-(+)$ (Raffa and Klepzig, 1989).

Lanierone (2-hydroxy-4,4,6-trimethyl-2,5-cyclohexadien-1-one) has been identified as a third male-produced aggregation pheromone for $I$. pini in New York (Teale et al., 1991). Attraction of both sexes to racemic ipsdienol is synergized by lanierone. However, the role of lanierone may not be the same throughout the broad transcontinental range of $I$. pini (Teale et al., 1991; Seybold et al., 1992).

The high degree of geographic variation in the use of ipsdienol enantiomers as pheromones by $I$. pini suggests that similar variation may also exist for 
lanierone. Lanierone was not detected in Porapak extracts from California (Seybold et al., 1992). Similarly, the effect of lanierone on the attraction of I. pini to ipsdienol is weaker in California than in New York (Seybold et al., 1992). Therefore we hypothesized that lanierone would not have the same effect on the response of $I$. pini to region-specific enantiomeric mixtures of ipsdienol throughout North America.

\section{METHODS AND MATERIALS}

Chemicals and Release Devices. Phero Tech Inc. (Delta, British Columbia) supplied the following types of polyvinyl, bubble-cap lures: (1) 1,3-butanediol (chemical purity, $>98 \%$ ); (2) racemic ipsdienol (chemical purity, $98 \%$ ) in solution with 1,3-butanediol; (3) $(R)$-(-)-ipsdienol (chemical purity, 98\%; optical purity, $>97 \%$ ) in solution with 1,3-butanediol; and (4) lanierone (chemical purity, $95 \%$ ) in solution with 1,3-butanediol. The release rates of 1,3-butanediol, ipsdienol [racemic and $(R)-(-)$ ], and lanierone were approximately $2,0.2$, and $0.02 \mathrm{mg} / \mathrm{day}$, respectively, at $24^{\circ} \mathrm{C}$ (determined by collection of volatiles on Porapak-Q). 1,3-Butanediol is not attractive to $I$. pini alone or in combination with ipsdienol (Miller, 1990).

Experimental Design. The same experiment was conducted at two sites in each of the following regions: (1) Syracuse, New York; (2) Madison, Wisconsin; (3) Missoula, Montana; (4) Kimberley, British Columbia; (5) Penticton, British Columbia; and (6) Hat Creek, California. At each site, 20 multiplefunnel traps (Lindgren, 1983) (Phero Tech Inc.) were set in five parallel lines of four traps per line. Each line of four traps constituted a replicate. Eight-unit funnel traps were used in California and New York, while 12-unit funnel traps were used in the remaining regions. Each trap was suspended by rope such that the bottom funnel of each trap was $0.5-1.0 \mathrm{~m}$ above ground level. No trap was within $1 \mathrm{~m}$ of any tree. Traps were set in the following types of stands: (1) lodgepole pine, Pinus contorta var. latifolia Engelmann, in British Columbia; (2) ponderosa pine, $P$. ponderosa Lawson, in Montana; (3) ponderosa and Jeffrey pines, $P$. jeffreyi Greville and Balfour, in Califormia; and (4) red pine, $P$. resinosa Aiton, in New York and Wisconsin. Sites were at least $1 \mathrm{~km}$ apart while traps were spaced 10-15 $\mathrm{m}$ apart within sites.

The following treatments were randomly assigned within each replicate: (1) 1,3-butanediol control; (2) ipsdienol with 1,3-butanediol; (3) lanierone with 1,3-butanediol; and (4) ipsdienol and lanierone with 1,3-butanediol. $(R)-(-)$ Ipsdienol was used in California and southeastern British Columbia. Racemic ipsdienol was used in the remaining regions. For most regions, the choice of enantiomeric compositions for ipsdienol was based upon regional specificities in production and response by I. pini (Birch et al., 1980; Lanier et al., 1980; 
Miller et al., 1989a, 1996; Raffa and Klepzig, 1989; Teale, 1990; Herms et al., 1991; Teale and Lanier, 1991; Seybold, 1992; Seybold et al., 1995). No previous studies had been conducted in Montana. We chose racemic ipsdienol, reasoning that populations in Montana would likely be similar to eastern populations.

The experiments were conducted in 1991 during the following periods: (1) July 18-31 in New York; (2) July 19-August 16 in Wisconsin; (3) July 12-29 in Montana; (4) June 27-July 11 in southeastern British Columbia; (5) July 3-August 17 in southwestem British Columbia; and (6) July 23-30 in California. Sexes of captured $I$. pini were determined, using declivital characters (Lanier and Cameron, 1969), for all beetles in small catches and for subsamples $(N=30-50)$ in large catches. Responses of associated beetle species were also recorded.

Statistics. Data were analyzed using the Systat statistical package ver. 5.02 (Systat, Inc., Evanston, Illinois). Trap catch data were transformed by $\ln (Y+1)$ to remove heteroscedasticity and subjected to analysis of variance (ANOVA) using the following model factors: (1) replicate nested within site, (2) site, (3) ipsdienol, (4) lanierone, (5) site $*$ ipsdienol, (6) site $*$ lanierone, (7) ipsdienol * lanierone, and (8) site $*$ ipsdienol * lanierone. For both male and female $I$. pini, differences in mean catches were determined using Tukey's HSD multiple-comparison test at $P=0.05$ (experiment-wise). Proportional increases were calculated for each replicate by dividing the difference in catches between the two treatments by the catch in the trap baited with ipsdienol alone.

Synergism between lanierone and ipsdienol was indicated by satisfying three statistical conditions. First, synergism required a significant interaction between these two factors in the ANOVA, indicating that the proportional increases (not absolute increases) due to both factors were not additive. Secondly, one factor (lanierone) had to be benign while the second factor (ipsdienol) had to be active. Multiple comparison tests such as Tukey's HSD can affirm that one factor is benign and does not differ from the control and that a second factor is attractive relative to the control. Lastly, the combination of lanierone and ipsdienol had to result in significantly higher catches than ipsdienol alone.

Sex ratio data for $I$. pini captured in ipsdienol-baited traps were normalized by arcsine $(Y)$, and analyzed by ANOVA using the following model factors: (1) replicate nested within site, (2) site, (3) lanierone, and (4) site $*$ lanierone. Mean proportions of males in traps baited with ipsdienol were compared to those in traps with ipsdienol and lanierone using a two-sided $t$ test. Differences in sex ratios among regions and among mean catches of other species were determined using Tukey's HSD multiple comparison test at $P=0.05$ (experimentwise). 
RESULTS

Ips Species. In all regions, lanierone and ipsdienol had significant effects on trap catches of both sexes (all $P \leq 0.035$ ) (Table 1). The interaction between ipsdienol and lanierone had a significant effect on males in all regions except southeastern British Columbia. The interaction had no significant effect on females in California and southeastern British Columbia.

The effects of lanierone varied between regions (Figure 1), with the most pronounced effect apparent in New York and Wisconsin. In general, the preferred treatment for both sexes was the combination of ipsdienol and lanierone (Tables 2 and 3), with synergism apparent in most regions. Lanierone was not attractive in Montana, southwestern British Columbia, Wisconsin, and New York. However, when added to ipsdienol, lanierone increased trap catches 260-9942\%. Lanierone did not increase catches of females in California. At one site in California, the addition of lanierone to ipsdienol resulted in a modest increase in trap catch of males.

Traps baited with lanierone alone did not generally catch more $I$. pini than control traps (Tables 2 and 3). The exception was in southeastern British Columbia where significantly more males and females were captured in traps baited with lanierone alone than in control traps. The mean proportional increases ranged from $107 \%$ to $878 \%$.

Lanierone, or the interaction between lanierone and site, had significant effects on the sex ratio of $I$. pini caught in ipsdienol-baited multiple-funnel traps in five of the six regions (Table 4). In California, southeastern British Columbia and New York, the mean proportion of males was greater in catches to traps baited with lanierone and epsdienol than in those to traps baited with ipsdienol alone (Table 5). The effect was weakly significant at site $A$ in southwestern British Columbia and site B in Wisconsin.

Sex ratios varied between regions for catches to traps baited with either ipsdienol alone or ipsdienol and lanierone (Table 5). In nine of 12 sites, the sex ratio in catches to traps baited with ipsdienol alone was generally female-biased (mean proportions of males ranging from 0.19 to 0.40). In Montana, the sex ratio was male-biased (mean proportions of males were 0.63 and 0.71 for sites $A$ and $B$, respectively). The sex ratios in catches of traps baited with ipsdienol and lanierone were generally close to $1: 1$. The exceptions were in Montana (male-biased) and southwestern British Columbia (female-biased).

Lanierone was attractive to I. integer (Eichhoff) in Montana (Figure 2). Significantly more beetles were caught in traps baited with lanierone alone than in those baited with any other treatment. The response to lanierone was strongly inhibited by racemic ipsdienol (ANOVA, $P<0.001, d f=1,24$ ). The mean catches to traps baited with ipsdienol and lanierone were not significantly dif- 


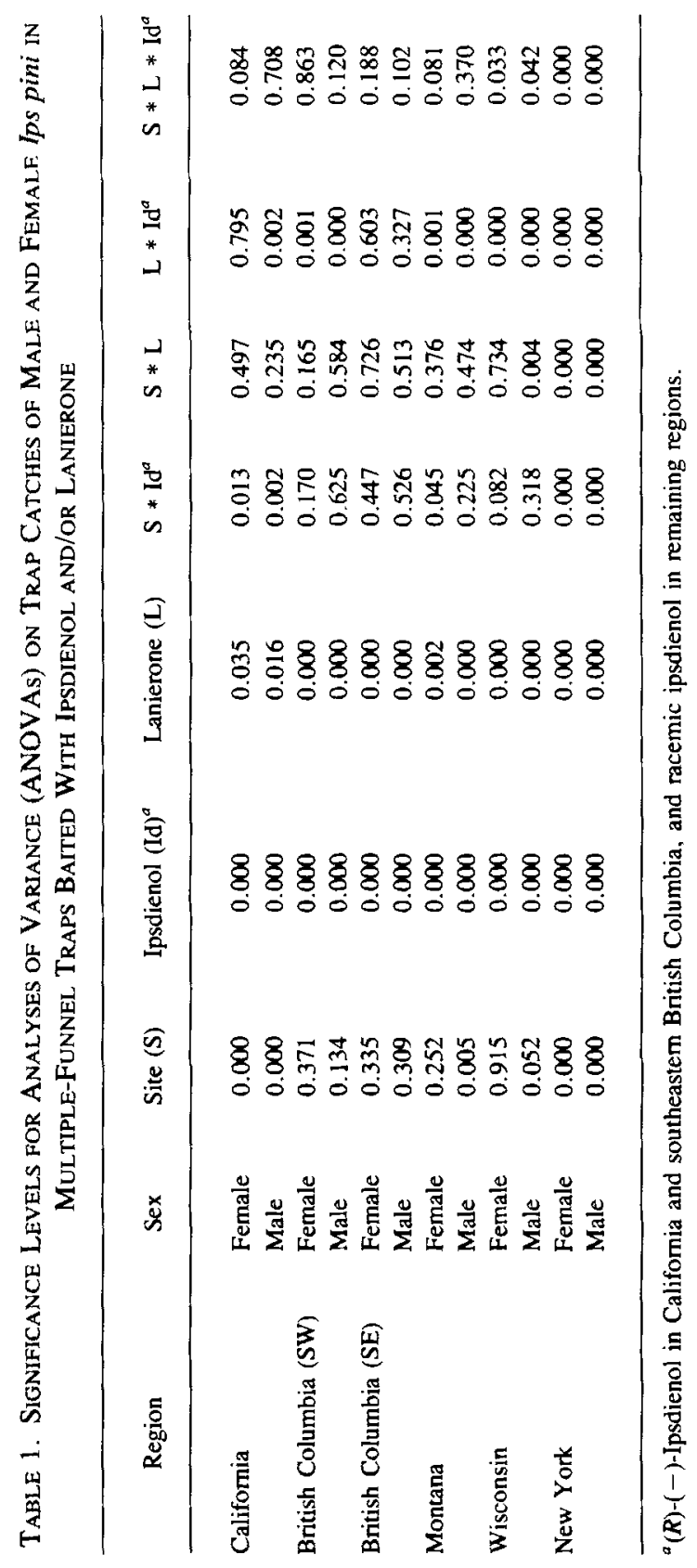




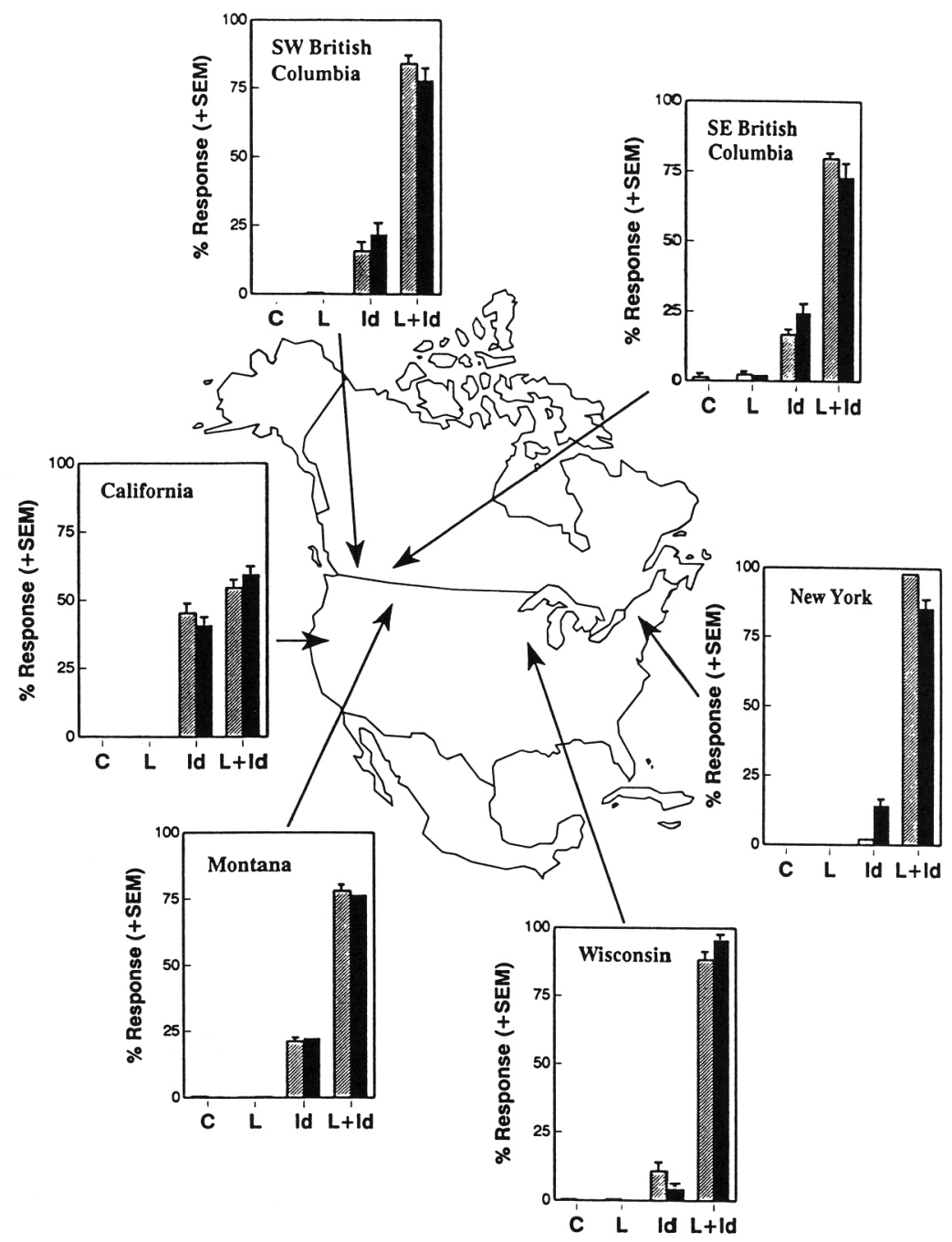

FIG. 1. Geographic variation in the response of Ips pini to multiple-funnel traps baited with lanierone (L) and/or ipsdienol (Id), relative to control traps $(C) .(R)-(-)$-Ipsdienol was used in southeastem British Columbia and Califomia. Racemic ipsdienol was used in the remaining regions. Data are presented as mean percentages of replicate catches for site A (striped bar) and site B (solid bar) in each region $(N=5)$. 


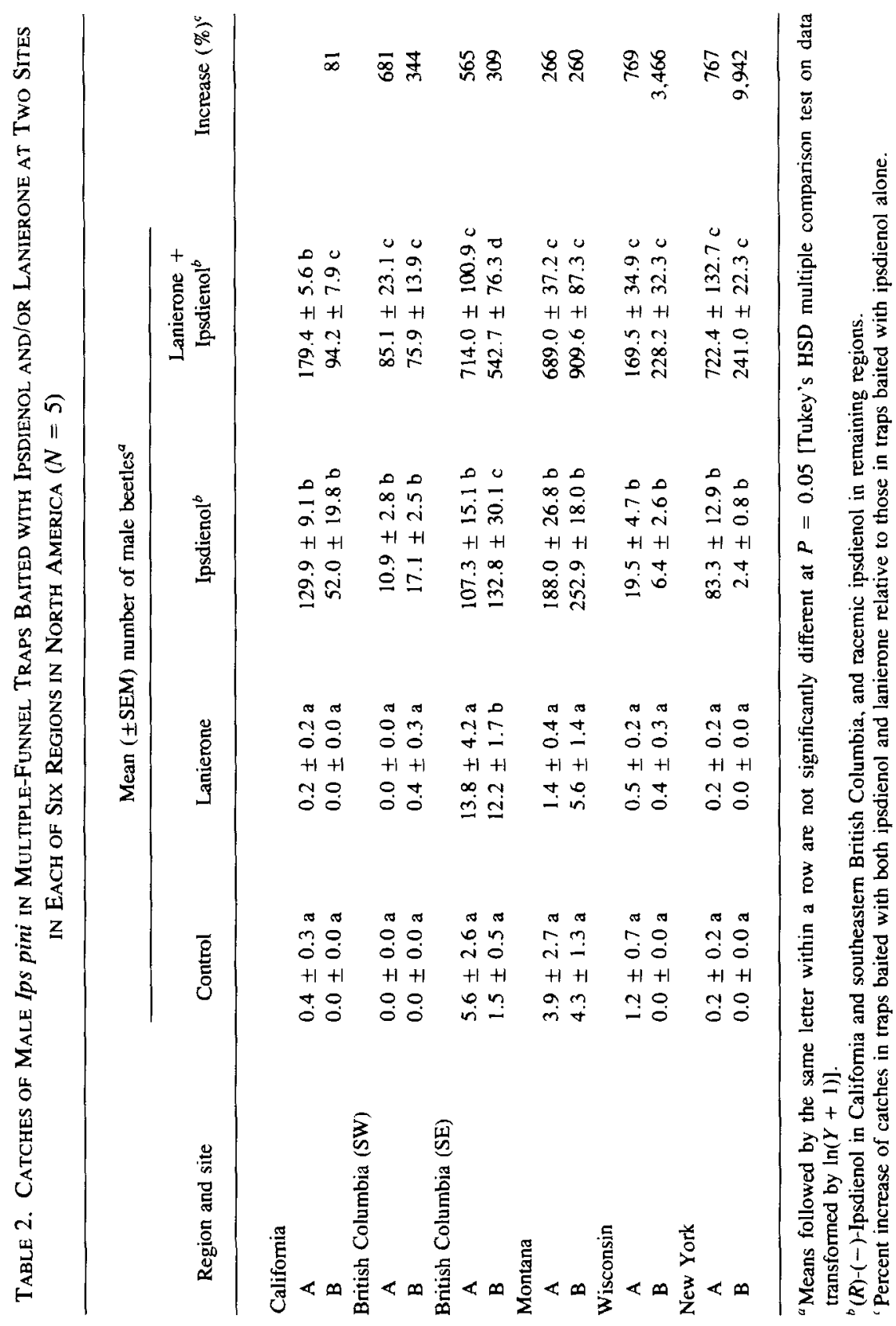




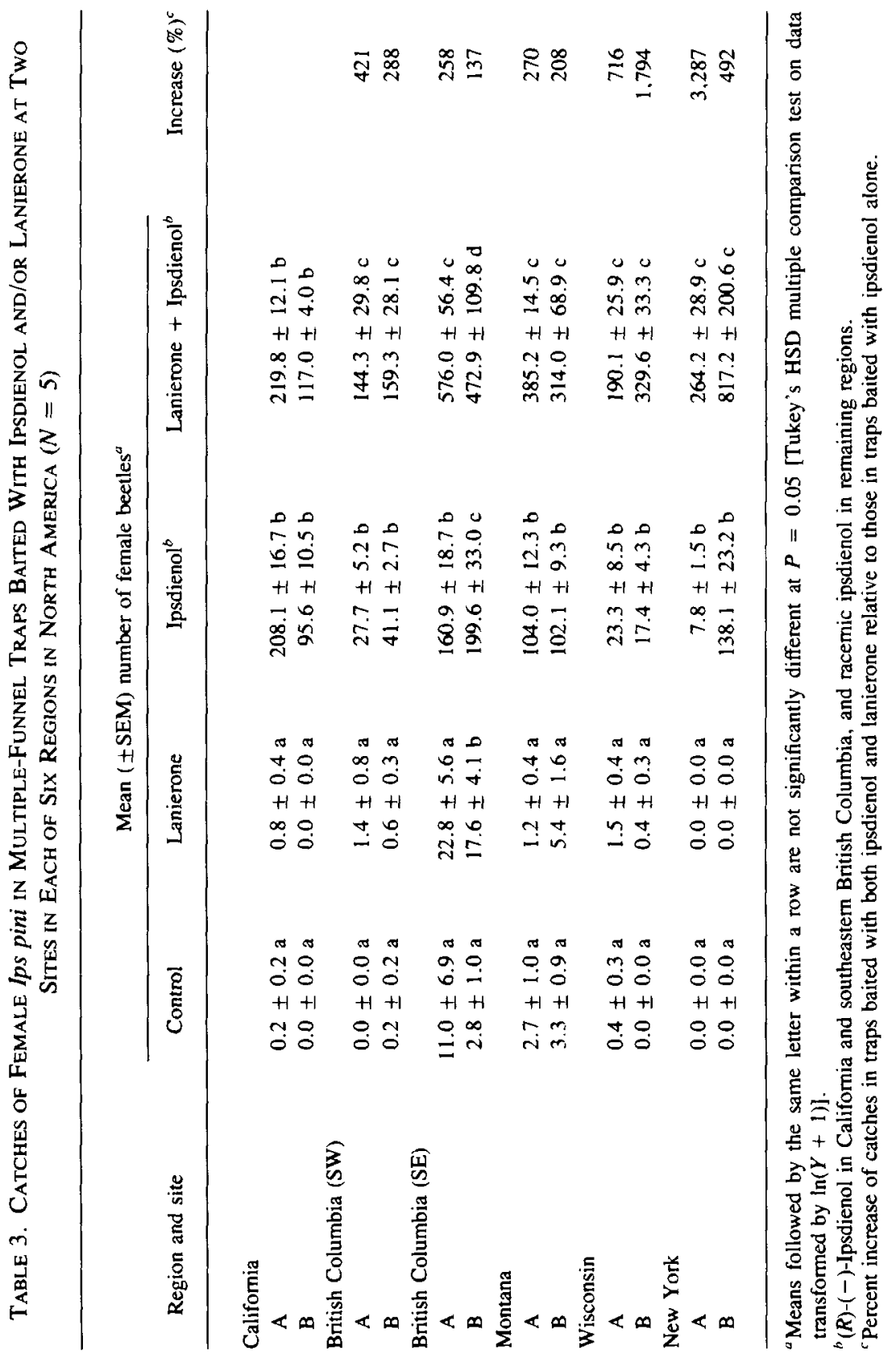


Table 4. Significance Levels for analyses of Variance (ANOVas) on Sex Ratios in Catches of Ips pini in IPSDiEnol-Baited Multiple-FunNel.

Traps in Six Regions of North America

\begin{tabular}{lccr}
\hline \multicolumn{1}{c}{ Region } & Site (S) & Lanierone (L) & S*L \\
\hline California & & & \\
British Columbia (SW) & 0.287 & 0.001 & 0.495 \\
British Columbia (SE) & 0.886 & 0.051 & 0.328 \\
Montana & 0.866 & 0.001 & 0.800 \\
Wisconsin & 0.033 & 0.562 & 0.567 \\
New York & 0.007 & 0.235 & 0.042 \\
& 0.017 & 0.001 & 0.023 \\
\hline
\end{tabular}

Table 5. Proportion of Male Ips pini in Ipsdienol-Baited Multiple-Funnfl Traps at Two Sites in Each of Six Regions in North America $(N=5)$

\begin{tabular}{|c|c|c|c|c|}
\hline \multirow[b]{2}{*}{ Region and site } & \multicolumn{2}{|c|}{ Mean ( \pm SEM) proportion of males ${ }^{a}$} & \multicolumn{2}{|c|}{$t$ test $^{h}$} \\
\hline & Ipsdienol $^{c^{\prime}}$ & $\begin{array}{l}\text { Lanierone + } \\
\text { ipsdienol }^{c}\end{array}$ & $d f$ & $P$ \\
\hline \multicolumn{5}{|l|}{ California } \\
\hline A & $0.38 \pm 0.02 \mathrm{abcd}$ & $0.45 \pm 0.02 \mathrm{abc}$ & 7.8 & 0.015 \\
\hline B & $0.35 \pm 0.02 \mathrm{abcd}$ & $0.44 \pm 0.02 \mathrm{abc}$ & 7.9 & 0.007 \\
\hline \multicolumn{5}{|c|}{ British Columbia (SW) } \\
\hline A & $0.26 \pm 0.04 \mathrm{abc}$ & $0.36 \pm 0.03 a b$ & 7.5 & 0.068 \\
\hline B & $0.29 \pm 0.02 \mathrm{abcd}$ & $0.32 \pm 0.02 \mathrm{a}$ & 7.6 & 0.258 \\
\hline \multicolumn{5}{|l|}{ British Columbia (SE) } \\
\hline A & $0.40 \pm 0.02 \mathrm{c}$ & $0.55 \pm 0.02 \mathrm{~cd}$ & 7.6 & .001 \\
\hline B & $0.38 \pm 0.03 \mathrm{c}$ & $0.55 \pm 0.04 \mathrm{~cd}$ & 7.1 & 0.017 \\
\hline \multicolumn{5}{|l|}{ Montana } \\
\hline A & $0.63 \pm 0.06 \mathrm{ef}$ & $0.64 \pm 0.02 \mathrm{de}$ & 4.7 & 0.996 \\
\hline B & $0.71 \pm 0.01 \mathrm{f}$ & $0.75 \pm 0.05 \mathrm{e}$ & 4.2 & 0.456 \\
\hline \multicolumn{5}{|l|}{ Wisconsin } \\
\hline A & $0.50 \pm 0.06 \mathrm{cde}$ & $0.46 \pm 0.04 \mathrm{abc}$ & 7.5 & 0.517 \\
\hline B & $0.23 \pm 0.08 \mathrm{abcd}$ & $0.41 \pm 0.03 \mathrm{abc}$ & 5.2 & 0.079 \\
\hline \multicolumn{5}{|l|}{ New York } \\
\hline A & $0.19 \pm 0.06 \mathrm{a}$ & $0.48 \pm 0.02 \mathrm{abc}$ & 5.1 & 0.003 \\
\hline B & $0.38 \pm 0.02 \mathrm{abcd}$ & $0.48 \pm 0.02 \mathrm{abc}$ & 7.9 & 0.004 \\
\hline
\end{tabular}

${ }^{a}$ Means followed by the same letter within a column are not significantly different at $P=0.05$ [Tukey's HSD multiple comparison test on data transformed by aresine $(Y)$ ].

"Two-sided test comparing proportions of males in traps baited with ipsdienol alone to those in traps baited with the combination of ipsdienol and lanierone.

${ }^{c}(R)-(-)$-Ipsdienol in California and southeastern British Columbia, and racemic ipsdienol in remaining regions. 


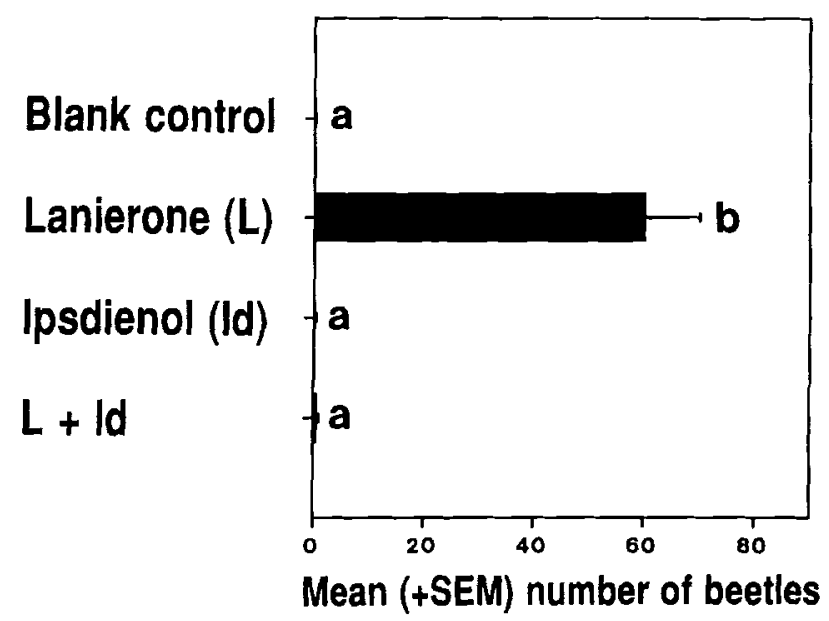

FIG. 2. Responses of Ips integer to multiple-funnel traps baited with lanierone and/or racemic ipsdienol in Missoula, Montana, from July 19 to $29,1991(N=10)$. Means followed by the same letter are not significantly different at $P=0.05$ [Tukey's HSD multiple comparison test on data transformed by $\ln (Y+1)]$.

ferent from the control traps (Figure 2). Racemic ipsdienol alone was not attractive. Ips integer were not caught at any other location.

Predators. Ipsdienol and or lanierone were attractive to six species of bark beetle predators. The preferred treatments for Enoclerus lecontei (Wolcott) (Cleridae) were the combination of lanierone and $(R)-(-)$-ipsdienol in California and southeastern British Columbia, and the combination of lanierone and racemic ipsdienol in Montana (Table 6). The attraction was synergistic in California (ANOVA, $P<0.001, d f=1,24$ ) but not in southeastem British Columbia and Montana (ANOVA; $P=0.616$ and $P=0.554$, respectively; $d f=1,24$ and $d f=1,24$, respectively). $(R)$-(-)-Ipsdienol was attractive to $E$. sphegeus $(\mathrm{F}$.) and Temnochila chlorodia (Mannerheim) (Trogositidae) in California and to Thanasimus undatulus (Say) (Cleridae) in southeastern British Columbia (Table 6). Similarly, E. nigrifrons var. gerhardi Wolc. and Thanasimus dubius (F.) in Wisconsin were attracted to racemic ipsdienol. None of these five species were affected by lanierone.

\section{DISCUSSION}

Our results are consistent with those of Teale (1990), Teale et al. (1991), and Seybold et al. (1992). Lanierone generally synergized the attraction of both male and female $I$. pini to the principal pheromones, $(R)-(-)$ - and $(S)-(+)-$ 


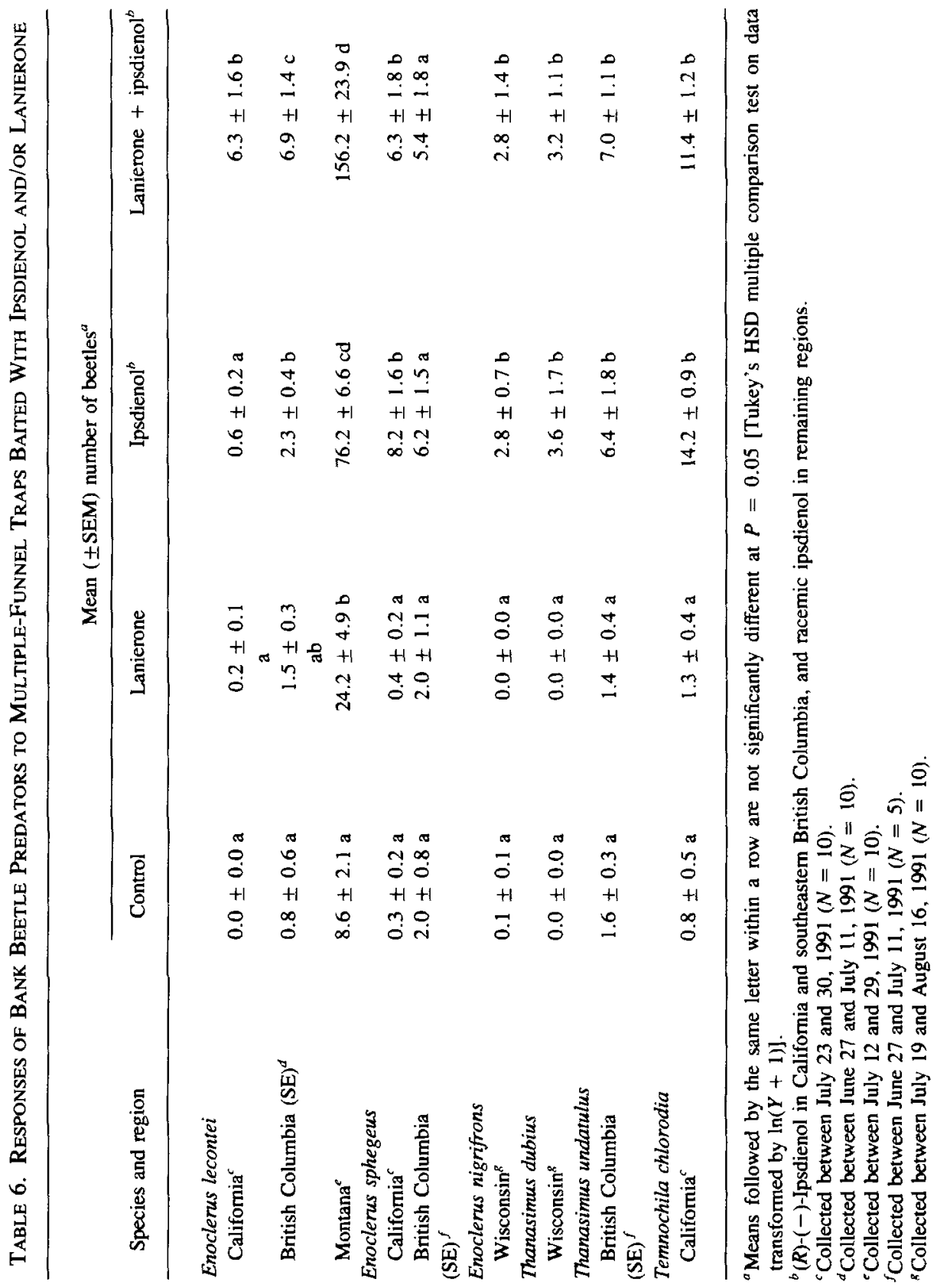


ipsdienol. By itself, lanierone was not very attractive. However, there were significant regional differences in the effects of lanierone on the responses of male and female $I$. pini.

Firstly, there was geographical variation in the mean proportional increases in catches to ipsdienol-baited, multiple-funnel traps due to the presence of lanierone. Synergism was most pronounced in both of the eastern regions. The mean proportional increases ranged from $492 \%$ to $9942 \%$ in eastern North America compared to a range of $0-681 \%$ in western regions. Lanierone had the least effect in California.

Secondly, southeastern British Columbia differed from other regions with respect to the effect of lanierone alone, and the interaction between ipsdienol and lanierone. This was the only region where lanierone was significantly attractive to $I$. pini by itself. The mean proportional increases in catches between control traps and those baited with lanierone alone ranged from $107 \%$ to $713 \%$. Further, southeastern British Columbia was the only region where the interaction between ipsdienol and lanierone was not significant $(P=0.603$ and $P=0.327$ for females and males, respectively). The lack of statistical significances associated with the interaction terms for males and females indicate that the proportional increases in trap catches due to the presence of lanierone was the same with and without ipsdienol. This was not true of most of the other sites, which clearly demonstrated synergism between ipsdienol and lanierone in the attraction of I. pini.

Lastly, the differences in sex ratios in catches to traps baited with ipsdienol and lanierone, relative to those in traps baited with ipsdienol alone, were clearly significant in three regions. In California, New York, and southeastern British Columbia, proportionally more males than females were attracted to traps baited with the binary mixture, resulting in a reduction in female bias. Yet lanierone had little effect on catches of males and females in California. Previous results in New York demonstrated that an increase in the proportion of lanierone resulted in an increase in the proportion of males (Teale et al., 1991). In a separate trial in California, Seybold et al. (1992) found that sex ratio of $I$. pini caught in ipsdienol-baited funnel traps was not affected by lanierone. In the three sites in this study where the sex ratio was either $1: 1$ or slightly male biased, there were no significant differences in sex ratio between the two ipsdienol treatments. Further, the increase in male representation in trap catches varied between sites in eastern regions but not in western ones.

Presently, we cannot fully explain all these observed variations. However, the following factors may be important. Firstly, geographic variation in the use of $(R)-(-)$ - and $(S)-(+)$-ipsdienol as a pheromone by $I$. pini is known to occur between populations in California and New York. Beetles in California produce and respond primarily to $(R)-(-)$-ipsdienol (Birch et al., 1980; Seybold, 1992). 
Attraction to $(R)-(-)$-ipsdienol is interrupted by $(S)-(+)$-ipsdienol. The sympatric species $I$. paraconfusus Lanier uses $(S)-(+)$-ipsdienol as one of its pheromones (Silverstein et al., 1966; Wood et al., 1968). The pheromones of I. pini and I. paraconfusus are mutually inhibitory in California, presumably to ensure reproductive isolation (Birch and Wood, 1975; Birch and Light, 1977; Birch, 1978; Light and Birch, 1979; Birch et al., 1980). Ips paraconfusus is not present east of Oregon and California (Wood, 1982) and eastern I. pini use both enantiomers of ipsdienol as pheromones (Stewart, 1975; Lanier et al., 1980; Teale and Lanier, 1991).

The lack of a strong increase in attraction of I. pini to ipsdienol-baited traps in California, when lanierone is added, may be a consequence of similar species specificity in the use of pheromones to ensure reproductive and/or ecological separation. The role of lanierone in the aggregation behavior of I. paraconfusus has not been studied. Seybold et al. (1992) could not detect lanierone in another potential competitor, Dendroctonus brevicomis LeConte. Ips integer was strongly attracted to lanierone in Montana but not detected in California or British Columbia, even though both regions are well within its range (Wood, 1982).

Either lanierone is not important as a pheromone to I. pini in California or only a specific mixture of lanierone and $(R)-(-)$-ipsdienol is active. Evidence by Seybold et al. (1992) seems to support the first hypothesis. However, they suggest that selection pressure from predation by $E$. lecontei may have favored I. pini that no longer used lanierone as a pheromone, similar to the model proposed for differential chiral and seasonal responses between $I$. pini and its major predators in Wisconsin (Raffa and Klepzig, 1989; Raffa, 1991). Yet, in southeastern British Columbia and Montana both E. leconte $i$ and I. pini responded strongly to the combination of ipsdienol and lanierone.

Regional differences in population levels may explain some of the variation. The mean replicate catches of $I$. pini per site were correlated with the mean proportion of males in catches to traps baited with ipsdienol alone and the mean proportion of males in catches to traps baited with ipsdienol and lanierone ( $r=0.623$ and $r=0.781$, respectively; $P=0.031$ and $P=0.003$, respectively). In contrast, the mean replicate catches of males and females per site were not correlated with the mean proportional increases in catches of males and females, respectively, in ipsdienol-baited traps due to the presence of lanierone $(r=0.220$ and $r=0.249$, respectively; $P=0.491$ and $P=0.436$, respectively). We should note, however, that the mean replicate catches of beetles may not be a good estimator of population size since the regions varied in trapping period and duration, stand structure, and temperature regime. Unfortunately, we do not have a better estimator.

Regional differences in the timing of life history activities relative to the trapping periods might also explain some of the variation. In California, responses 
of male and female $I$. pini to extracts of male frass were lowest during the winter months, presumably due to diapause-related decreased receptiveness and/or decreased pheromone production (Birch, 1974). In New York and Wisconsin, most $I$. pini respond to synthetic ipsdienol late in the season (Teale, 1990; Raffa, 1991; Teale and Lanier, 1991). However, in Wisconsin in 1990, catches of beetles in ipsdienol-baited funnel traps were as high in April as they were in June and August (Raffa, 1991).

We should expect changes in the operational sex ratio (Emlen and Oring, 1977) during the course of an attack as well. The sex ratio among Dendroctonus ponderosae Hopkins landing on lodgepole pine changes during the colonization period, with the proportion of females declining over time (Raffa and Berryman, 1983). In this study, the operational sex ratio is defined as the ratio of active, searching males to available, unattached females, thereby omitting those beetles that are occupied in activities under the bark such as mating or egg laying. Males initiate the attacks and then produce pheromones while they wait for females. This results in local depletions of males available for capture in pheromone-baited traps. Ips pini is a polygynous species, with males having three to four females per harem (Thomas, 1961). Once harems are fully established, the operational sex ratio should become male biased with two to three times as many females as males under the bark. If males exhibit defensive behaviors by remaining in the gallery after females have left, then once again we would expect female bias in the operational sex ratio. Therefore, variation in sex ratios between regions may be due to variation in sampling periods relative to the sequence of behaviors during attack. Beetles in some regions may have only begun to attack new host material while beetles in other regions may have been well into the last stages of the behaviors associated with attacks.

There are three additional factors that may contribute to regional differences in the operational sex ratio. Firstly, attacks by bark beetles on suitable hosts are sequential. Activities at one gallery may not be synchronous with activities in galleries farther up the trunk of a tree (see reviews in Coulson, 1979; Berryman, 1982). Secondly, if males have a propensity to disperse prior to attack, then this would result in additional depletion of males. The sex ratio among I. pini attacking new host material is generally female biased at 2 females/male (Schenk and Benjamin, 1969; Schmitz, 1972). Lastly, the male bias detected in Montana may have resulted from the use of racemic ipsdienol in this region. Past studies in British Columbia and California have demonstrated that the proportion of males captured in ipsdienol-baited traps is correlated with the proportion of $(S)-(+)$-ipsdienol used in the lures (Miller, 1990; Seybold, 1992). Males in Montana produce ipsdienol with an enantiomeric composition of $91: 9$ to $95: 5$ $(R)-(-):(S)-(+)$ (Seybold et al., 1995). Male bias in trap catches might have been reduced if $(R)-(-)$-ipsdienol had been used instead of racemic ipsdienol.

Examples of geographic variation in the use of pheromones have commonly 
been reported for Lepidoptera (Roelofs, 1980; Cardé and Baker, 1984). The European corn borer, Ostrinia nubilalis (Hübner) (Pyralidae), uses 11 -tetradecenyl acetate (11-14:OAc) as a sex pheromone (Klun, 1968; Klun and Brindley, 1970; Klun and Robinson, 1971). Geographic variation is based on the relative proportion of the $E$ and $Z$ isomers of 11-14:OAc (Klun et al., 1973; Kochansky et al., 1975). Most populations in Europe and North America respond to a $3: 97 E: Z$ ratio of $11-14:$ OAc, while populations in Italy, the Netherlands, and parts of northeastern United States respond preferentially to a 97:3 E:Z blend (Klun and Cooperators, 1975). Some areas, such as New York state, have discrete populations using only the $3: 97 E: Z$ blend as well as hybrid populations (Roelofs et al., 1985). In California, at least three different populations of the western avocado leafroller, Amorbia cuneana (Walsingham) (Tortricidae), differ in the production of $E: Z$ blends of the sex pheromone, $(E, E / Z)-10,12$-tetradecadien-1-ol acetate. Two populations respond to blends close to $1: 1$, while the third prefers blends with a higher $E: Z$ ratio (Bailey et al., 1986). In New Zealand, brown-headed leafrollers, Ctenopseustis obliquana (Walker) (Tortricidae), exhibit two different pheromone population types. One uses an 80:20 mix of $(Z)$-8-tetradecenyl and $(Z)$-5-tetradecenyl acetates, while the other uses only (Z)-5-tetradecenyl acetate (Foster and Roelofs, 1987).

Our results and those of others (Birch et al., 1980; Lanier et al., 1980; Miller et al., 1989a, 1996; Raffa and Klepzig, 1989; Teale, 1990; Teale et al., 1991; Seybold, 1992; Seybold et al., 1992, 1995) with I. pini support the need for tests over its full geographical range. Pheromone blends differ substantially between areas, necessitating the use of regionally specific lures for pest management. Our results indicate that a blend of racemic ipsdienol and lanierone is optimal for most regions while $(R)$-( $(-)$-ipsdienol by itself is sufficient for use in California. Regional pheromone specificity, and the need for tests throughout geographic ranges, may be important for other scolytid species as well. In laboratory bioassays, the southern pine beetle, Dendroctonus frontalis Zimmerman, collected from Georgia, Texas, and Virginia, showed marked preferences for pheromones from their respective regions (Berisford et al., 1990). A standard lure of frontalin, trans-verbenol, and turpentine was as attractive as the regional blends in Georgia and Texas, but not in Virginia.

Bark beetle pheromones are used as kairomones by predators (Borden, 1982; Dahlsten, 1982; Miller et al., 1989b; Payne, 1989). Temnochila chlorodia, Enoclerus sphegeus, E. nigrifrons, Thanasimus undatulus, and $T$. dubius were all attracted to ipsdienol. These results are consistent with those of Vité and Gara (1962), Wood et al. (1968), Furniss and Livingston (1979), Raffa and Klepzig (1989), Miller and Borden (1990), and Seybold et al. (1992). Similar research has demonstrated that $E$. lecontei is also attracted to ipsdienol (Wood et al., 1968; Miller and Borden, 1990). Our results further show attraction of $E$. lecontei to ipsdienol and lanierone in three different regions. As found by 
Seybold et al. (1992), synergism occurred between ipsdienol and lanierone in attracting $E$. lecontei in California. Synergism did not occur in British Columbia or Montana. We suggest that synergism may reflect differential benefits for $E$. lecontei in California, compared to $E$. lecontei in British Columbia and Montana, resulting in a greater measure of prey specificity in California, relative to other regions.

Acknowledgments-We thank two anonymous reviewers for their comments. J. P. Lafontaine and D. A. Wakarchuk synthesized lanierone and $(R)-(-)$-ipsdienol. Phero Tech Inc. supplied all lures. Field and laboratory assistance were provided by J. Davis, R. Hofstetter, K. Jackson, B. S. Lindgren, N. Lewis, and $J$. Tupy. Y. Bousquet and E. Rickey kindly verified the identifications of Trogositidae and Cleridae, respectively. Voucher specimens have been deposited with the Entomology Museum at Simon Fraser University. This research was partially supported by a cooperative research agreement (PSW-92-0014CA) with D.L.W. and the Pacific Southwest Research Station, Forest Service, US Department of Agriculture, Albany, Califomia.

\section{REFERENCES}

Bailey, J. B., McDonough, L. M., and Hoffman, M. P. 1986. Western avocado leafroller, Amorbia cuneana (Walsingham), (Lepidoptera: Tortricidae). Discovery of populations utilizing different ratios of sex pheromone components. J. Chem. Ecol. 12:1239-1245.

Berisford, C. W., PAyne, T. L., and Berisford, Y. C. 1990. Geographical variation in response of southern pine beetle (Coleoptera: Scolytidae) to aggregating pheromones in laboratory bioassays. Environ. Entomol. 19:1671-1674.

Berryman, A. A. 1982. Population dynamics of bark beetles, pp. 264-314, in J. B. Mitton and K. B. Sturgeon (eds.). Bark Beetles in North American Conifers. University of Texas Press, Austin, Texas.

BirCH, M. C. 1974. Seasonal variation in pheromone-associated behavior and physiology of Ips pini. Ann. Entomol. Soc. Am. 67:58-60.

BIRCH, M. C. 1978. Chemical communication in pine bark beetles. Am. Sci. 66:409-419.

BIRCH, M. C., and LIGHT, D. M. 1977. Inhibition of the attractant pheromone response in Ips pini and I. paraconfusus (Coleoptera: Scolytidae): Field attraction of ipsenol and linalool. J. Chem. Ecol. 3:257-267.

BIRCH, M. C., and WoOD, D. L. 1975. Mutual inhibition of the attractant pheromone response by two species of Ips (Coleoptera: Scolytidae). J. Chem. Ecol. 1:101-1 I3.

Birch, M. C., Light, D. M., Wood, D. L., Browne, L. E., Silverstein, R. M., Bergot, B. J., OHLOFF, G., West, J. R., and Young, J. C. 1980. Pheromonal attraction and allomonal intermution of Ips pini in California by the two enantiomers of ipsdienol. J. Chem. Ecol. 6:703-717.

BoRden, J. H. 1982. Aggregation pheromones, pp. 74-139, in J. B. Mitton and K. B. Sturgeon (eds.). Bark Beetles in North American Conifers. University of Texas Press, Austin, Texas.

CARdÉ, R. T., and BAKER, T. C. 1984. Sexual communication with pheromones, pp. 355-383, in W. J. Bell and R. T. Cardé (eds.). Chemical Ecology of Insects. Chapman and Hall, New York.

Coulson, R. N. 1979. Population dynamics of bark beetles. Annu. Rev. Enromol. 24:417-447.

DAHLSTEN, D. L. 1982. Relationships between bark beetles and their natural enemies, pp. 140-182, in J. B. Mitton and K. B. Sturgeon (eds.). Bark Beetles in North American Conifers. University of Texas Press, Austin, Texas. 
EMLEN, S. T., and ORING, L. W. 1977. Ecology, sexual selection, and the evolution of mating systems. Science 197:215-223.

Foster, S. P., and RoELOFs, W. L. 1987. Sex pheromone differences in populations of the brownheaded leafroller, Ctenopseustis obliquana. J. Chem. Ecol. 13:623-629.

FuRniss, M. M., and LivingSTON, R. L. 1979. Inhibition by ipsenol of pine engraver attraction in northern Idaho. Environ. Entomol. 8:369-372.

Herms, D. A., HAACK, R. A., and Ayres, B. D. 1991. Variation in semiochemical-mediated prey-predator interaction: Ips pini (Scolytidae) and Thanasimus dubits (Cleridae). J. Chem. Ecol. 17:1705-1714.

KLUN, J. A. 1968. Isolation of a sex pheromone of the European com borer. J. Econ. Entomol. $61: 484-487$.

KLUn, J. A., and Brindey, T. A. 1970. cis-11-Tetradecenyl acetate, a sex stimulant of the European com borer. J. Econ. Entomol. 63:779-780.

KLUN, J. A., and COOPERATORs. 1975. Insect sex pheromones: Intraspecific pheromonal variability of Ostrinia nubilalis in North America and Europe. Environ. Entomol. 4:891-894.

KLUN, J. A., and RoBinson, J. F. 1971. European com borer moth: Sex attractant and sex attraction inhibitors. Ann. Entomol. Soc. Am. 64:1083-1086.

Klun, J. A., Chapman, O. L., Matres, K. C., Wojtkowski, P. W., Beroza, M., and Sonnet, P. E. 1973. Insect sex pheromones: Minor amount of opposite geometrical isomer critical to attraction. Science 181:661-663.

Kochansky, J., Cardé, R. T., Liebherr, J., and Roelofs, W. L. 1975. Sex pheromone of the European corn borer, Ostrinia nubilalis (Lepidoptera: Pyralidae), in New York. J. Chem. Ecol. 1:225-231.

Lanier, G. N., and Cameron, E. A. 1969. Secondary sexual characters in the North American species of the genus Ips (Coleoptera: Scolytidae). Can. Entomol. 101:862-870.

lanier, G. N., Classon, A., Stewart, T., Piston, J. J., and Silverstein, R. M. 1980. Ips pini: The basis for interpopulational differences in pheromone biology. J. Chem. Ecol. 6:677-687.

Light, D. M., and BIRCH, M. C. 1979. Inhibition of the attractive pheromone response in Ips paraconfusus by $(R)-(-)$-ipsdienol. Naturwissenschaften $66: 159-160$.

Lindgren, B. S. 1983. A multiple-funnel trap for scolytid beetles. Can. Entomol. 115:299-302.

MiLLER, D. R. 1990. Reproductive and ecological isolation: Community structure in the use of semiochemicals by pine bark beetles (Coleoptera: Scolytidae). PhD thesis. Simon Fraser University, Burnaby, British Columbia, $166 \mathrm{pp}$.

MILLeR, D. R., and Borden, J. H. 1990. B-Phellandrene: Kairomone for pine engraver, Ips pini (Say) (Coleoptera: Scolytidae). J. Chem. Ecol. 16:2519-2531.

Miller, D. R., Borden, J. H., and Slessor, K. N. 1989a. Inter- and intrapopulation variation of the pheromone, ipsdienol, produced by male pine engravers, Ips pini (Say) (Coleoptera: Scolytidae). J. Chem. Ecol. 15:233-247.

Miller, M. C., McGregor, M., Dahlsten, D. L., Whitmore, M. C., Gregolre, J.-C., Jia-Xi, Z., Werner, R. A., Chow, Y. S., Tovar, D. C., Balanos, R. C., and Mendel, Z. 1989b. Responses of insect associates of allied species to Dendroctonus and Ips (Coleoptera: Scolytidae) aggregation pheromones: a search for biological control agents, pp. 213-229, in D. L. Kulhavy and M. C. Miller (eds.). Potential for Biological Control of Dendroctonus and Ips Bark Beetles. Stephen F. Austin State University Press, Nacogdoches, Texas.

Miller, D. R., Borden, J. H., and Slessor, K. N. 1996. Enantiospecific pheromone production and response profiles for populations of pine engraver, Ips pini (Say) (Coleoptera: Scolytidae), in British Columbia. J. Chem. Ecol. 22:2157-2172.

Payne, T. L. 1989. Olfactory basis for insect enemies of allied species, pp. 55-69, in D. L. Kulhavy and M. C. Miller (eds.). Potential for Biological Control of Dendroctonus and Ips Bark Beetles. Stephen F. Austin State University Press, Nacogdoches, Texas. 
RAFFA, K. F. 1991. Temporal and spatial disparities among bark beetles, predators, and associates responding to synthetic bark beetle pheromones: Ips pini (Coleoptera: Scolytidae) in Wisconsin. Environ. Entomol. 20:1665-1679.

RafFa, K. F., and Berryman, A. A. 1983. The role of host plant resistance in the colonization behavior and ecology of bark beetles (Coleoptera: Scolytidae). Ecol. Monogr. 53:27-49.

RAFFA, K. F., and KLEPZIG, K. D. 1989. Chiral escape of bark beetles from predators responding to a bark beetle pheromone. Oecologia 80:566-569.

Roelofs, W. L. 1980. Pheromones and their chemistry, pp. 508-602, in M. Locke and D. S. Smith (eds.). Insect Biology in the Future "VBW 80." Academic Press, New York.

Roelofs, W. L., Du, J.-W., TANG, X.-H., Robbins, P. S., and Eckenrode, C. J. 1985. Three European com borer populations in New York based on sex pheromones and voltinism. J. Chem. Ecol. 11:829-836.

SChenk, J. A., and Benjamin, D. M. 1969. Notes on the biology of lps pini in central Wisconsin jack pine forests, Pinus banksiana. Ann. Entomol. Soc, Am. 62:480-485.

ScHmITZ, R. F. 1972. Behavior of lps pini during mating, oviposition, and larval development (Coleoptera: Scolytidae). Can. Entomol. 104: 1723-1728.

SEYBold, S. J. 1992. The role of chirality in the olfactory-directed aggregation behavior of pine engraver beetles in the genus Ips (Coleoptera: Scolytidae). PhD thesis. University of California, Berkeley, Califomia, 355 pp.

Seyrold, S. J., Teale, S. A., Wood, D. L., Zhang, A., Webster, F. X., Lindahl, K. Q., Jr. and KUвo, I. 1992. The role of lanierone in the chemical ecology of Ips pini (Coleoptera: Scolytidae) in California. J. Chem. Ecol. 18:2305-2329.

SEybold, S. J., OHTSUKA, T., WOOD, D. L., and KUBo, I. 1995. Enantiomeric composition of ipsdienol: A chemotaxonomic character for North American populations of Ips spp. in the pini subgeneric group (Coleoptera: Scolytidae). J. Chem. Ecol. 21:995-1016.

Silverstein, R. M., Rodin, J. O., and WoOD, D. L. 1966. Sex attractants in frass produced by male Ips confusus in ponderosa pine. Science 154:509-510.

STEWART, T. E. 1975. Volatiles Isolated from Ips pini: Isolation, identification, enantiomeric composition, biological activity, and the enantiomeric composition of other insect pheromone alcohols and bicyclic ketals. MSc thesis. College of Environmental Science and Forestry, State University of New York, Syracuse, New York, 135 pp.

Teale, S. A. 1990. Ecology and evolution of pheromone communication in Ips pini (Coleoptera: Scolytidae). PhD thesis. College of Environmental Science and Forestry, State University of New York, Syracuse, New York, 109 pp.

Teale, S. A., and Lanier, G. N. 1991. Seasonal variability in response of lps pini (Coleoptera: Scolytidae) to ipsdienol in New York: J. Chem. Ecol. 17:1145-1158.

Teale, S. A., Webster, F. X.. Zhang, A., and Lanier, G. N. 1991. Lanierone: A new pheromone component from Ips pini (Coleoptera: Scolytidae) in New York. J. Chem. Ecol. 17:1159-1176.

Thomas, J. B. 1961. The life history of Ips pini (Say) (Coleoptera: Scolytidae). Can. Entomol. 93:384-390.

VITÉ, J. P., and GARA, R. I, 1962. Volatile attractants from ponderosa pine attacked by bark beetles (Coleoptera: Scolytidae). Contrib. Boyce Thompson Inst. 21:251-273.

Wood, D. L., Browne, L. E., Bedard, W. D., Tilden, P. E., Silverstein, R. M., and Rodin, J. O. 1968. Response of Ips confusus to synthetic sex pheromones in nature. Science 159:1373-1374.

WoOD, S. L. 1982. The bark and ambrosia beetles of North and Central America (Coleoptera: Scolytidae), a taxonomic approach. Great Basin Nat. Mem. 6. 